\title{
Middle Triassic crust-mantle interaction and crustal reworking in North Wulan Terrane: Response to subduction of the Paleo-Tethys Ocean
}

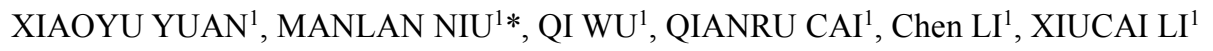

\author{
${ }^{1}$ School of Resources and Environmental Engineering, Hefei University of Technology, Hefei 230009, China
} (yly19941224@163.com, *correspondence: hfnml@hfut.edu.cn)

\begin{abstract}
Numerous Indosinian magmatic rocks in North Wulan Terrane, Northeastern margin of the Qaidam Basin, provide important insights into the mechanism and process for crust-mantle interaction and crustal reworking during the subduction of Paleo-Tethys Ocean [1]. In this work, an integrated study of field investigation, petrography, whole-rock major- and trace- elements as well as zircon Lu-Hf isotopes was conducted on Triassic gabbros and granitoids from the Chahannuo and Chanhanhe plutons in North Wulan Terrane. LA-ICP-MS zircon dating gave consistently middle Triassic ages of 246-242 Ma. These rocks have arc-like trace element distribution patterns, such as enrichment in LREEs and LILEs but depletion in HREEs and HFSEs. The gabbros have high $\mathrm{MgO}, \mathrm{Cr}$, Ni contents and $\mathrm{Mg}^{\#}$ values, and negative zircon $\mathrm{EHf}_{\mathrm{f}} \mathrm{t}$ ) values (-4.8 to -0.2 ), suggesting the derivation of an enriched lithospheric mantle that had been modified by the fluids/melts released from subducted slab. The diorites and granodiorites exhibit disequilibrium microscopic textures, i.e., sieved- and zoned- plagioclases, acicular apatite, and irregular biotite enclosed by amphibole. They also have extremely variable zircon $\varepsilon \mathrm{Hf}(\mathrm{t})$ values of -7.2 to +3.2 , varying between those of the gabbros and granites. Furthermore, mafic microgranular enclaves were unevenly distributed in the granodiorites. Therefore, it is inferred that the diorites and granodiorites were likely generated by mixing of enriched lithospheric mantle-derived mafic magmas and continental crust-derived felsic magmas. The granites are characterized by high contents of $\mathrm{SiO}_{2}, \mathrm{~K}_{2} \mathrm{O}$ and markedly negative $\mathrm{Sr}, \mathrm{Ba}$ and $\mathrm{Eu}$ anomalies as well as negative zircon $\varepsilon_{\mathrm{Hf}}(\mathrm{t})$ values of -5.87 to -1.77 . Accordingly, they were products of the remelting of lower continental crust with subsequently intensive fractionation. In addition, the zircon Hf isotopic compositions of those granitoids were identical with Early Paleozoic and Neoproterozoic crystalline basements in the North Wulan Terrane, but distinct from the Neoarhcean to Paleoproterozoic rocks in the Dakendaban Group [2]. This indicates that the lower continental materials were dominated by the Early Paleozoic and Neoproterozoic arc magmatic rocks. The aforementioned evidences demonstrated that the lithospheric mantle in North Wulan Terrane had experienced interaction with subduced oceanic crust, and the northward subduction of the Paleo-Tethys Ocean triggered the partial melting of the enriched mantle and lower continental crust, and resultant mixing between mafic- and felsic- magmas.
\end{abstract}

[1] Yan et al. (2012) Earth Science Frontiers 19, 164-176. [2] Chen et al. (2013) Precambrian Research 228, 102-116. 